\title{
Studies on Visual Recognition of an Agricultural Autonomous Tractor - Detection of the Field State by Image Processing -
}

\author{
Hideo HaSEgaWA*, Tomohiro TAKIGAWA*, Masayuki KoIKE*, \\ Akira YodA* and Naoki SAKAI**
}

\section{Introduction}

As the use of autonomous tractors are expected to spread as a major power source for precision agriculture in the future, basic research is actively being pursued at home and abroad. Because of its nature, plowing seems to play a very important role in field preparation. To develop an autonomous tractor, therefore, the first thing to consider is that the tractor should be capable of recognizing the field state as well as knowing its own position. On the other hand, the use of image processing technology has started spreading rapidly thanks to astounding progress in algorithms and other software techniques as well as in hardware typified by personal computers. In Japan, there have been reported a number of researches using image processing, including work on the detection of crop rows and the tractor's own position (Kanuma et al. 1997; Torii et al. 1997), work on the detection of ridges in a paddy field (Chen et al. 1998, 1999), and research on the use of knowledge system in image processing (Hirooka et al. 1997, Irimajiri et al. 1995). But little work has been reported as to the recognition of field plow states through image processing. We therefore aimed at developing a technique that allows an autonomous tractor to do work by recognizing the field state concerned (Hasegawa et al. 1998, 1999). To this end we employed image processing technique, which is now available relatively economically with a wider scope of application compared with sensors. This paper reports a number of things we found with respect to visual recognition of an autonomous tractor by using a program we developed to recognize plowed and unplowed portions of a field.

\section{Analytical Device and Methods}

Test images were collected at the field for forage crops of the Agricultural and Forestry Research Center, Tsukuba University. For plowing, we used a MasseyFerguson MF-365-4 tractor and Sugano TROY1622DCH reversible plow. Animation images of the field were taken by using a Sony DCR-PC7 digital video camera. They were entered to a personal computer (CPU: Pen-tium II 266MHz) through a color image processing board (Imagenation PXC200). (See Figure 1.) The image data entered was processed by an image processing program created in an image processing development environment (Halcon, MVTec). In the first place, we selected from the animation images those seemed to be important to recognize the field state and converted them into static images for analysis to examine the appropriateness of various parameters set for testing. Then, on the basis of the result of static image analysis, we conducted analysis for real-time recognition of animation images. The procedure we employed for analyzing static images was as follows: we took animation images of the field and input them to a static image capture board (Sony DVBK-W2000). Then, we obtained 24-bit color static images obtained for processing by the image processing program we created. To analyze animated images, we entered them

Received August 19, 1999

Accepted July 14, 2000

*Institute of Agricultural and Forest Engineering, University of Tsukuba, Tsukuba-shi, Ibaraki, 305-8572, Japan

**Institute of Agriculture and Forestry, University of Tsukuba, Tsukuba-shi, Ibaraki, 305-8572, Japan 


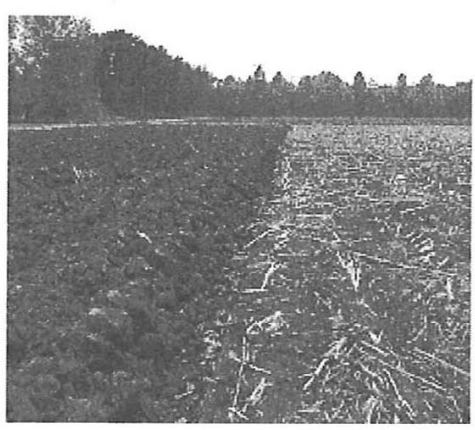

Field

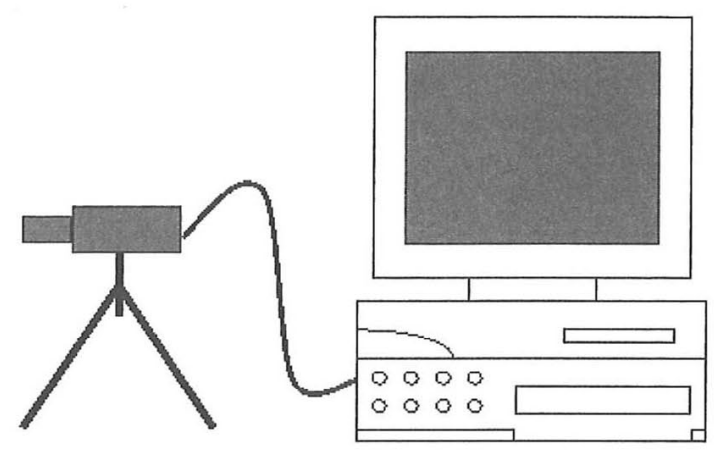

Digital Camera
Personal Computer

Fig. 1 Schematic Diagram

direct to a color image processing board for real-time analysis. These animation images included those of the tilled portion of the tractor alone against the background of the field and those of both tillage and no-tillage portions. We then handled the animation images successively by using the image processing program and tried to recognize boundary regions applying the processing procedure which we will discuss later. The image processing program was converted to an executable format through compilation with Microsoft Visual $\mathrm{C}++5.0$. Figure 2 shows the operation procedure of our image processing program with its characteristic processing operations: an animation images (or a static image) taken into the color image processing board is resolved into rectangles of specified size and then divided into areas of the same brightness. If there are two adjoining rectangles, the gray value at the center of each rectangular is used to determine whether or not they belong to the same region. If the difference between the two gray values is equal to or less than the tolerance, the two rectangles are combined as one region.

$$
\left|g_{-} 1-g_{-} 2\right| \leq \text { Tolerance }
$$

where, $g_{-} 1$ and $g_{-} 2$ represent the gray values of two adjoining regions, respectively. In our project, the tolerance was set at 15 .

Then, conditional region selection is done based on a shape-specific feature of each region. Specified feature value are obtained for each input region derived from expression (1). At this stage, we used the height of region as the shape-specific feature value and selected all regions that fell within specified upper and lower limit values.

$$
\text { Minimum_ } i \leq \text { Feature_ } i \leq \text { Maximum_ } i
$$

where, Minimum_ $i$ represents the minimum value of the features to cover, Feature_ $i$ a shape-specific feature (the height of each region), and Maximum_ $i$ the maximum value of features to cover.

The region is then closed by using the rectangular structure element. With this operation, a smooth area which is smaller than the rectangular structure element is to be closed.

Then, we generated a lattice-shaped region comprising lines and/or pixels. That is, a lattice region was made from the pixel at $(0,0)$ in the test field image to the pixel at (Height-1, Width-1) with a width of two steps in the row direction and a width of 1000 steps in the column direction.

Next, the intersection of the two regions is to be calculated. Specifically, we calculated the intersection of the previously calculated closed region and the latticeshaped region.

In the next step, the connecting element of the input region obtained from the intersecting region needs to be determined. To determine the connecting element of the foreground, we made the 8-neighborhood as the initial value.

Once again, conditional region selection is done based on a shape-specific feature as explained with expression 


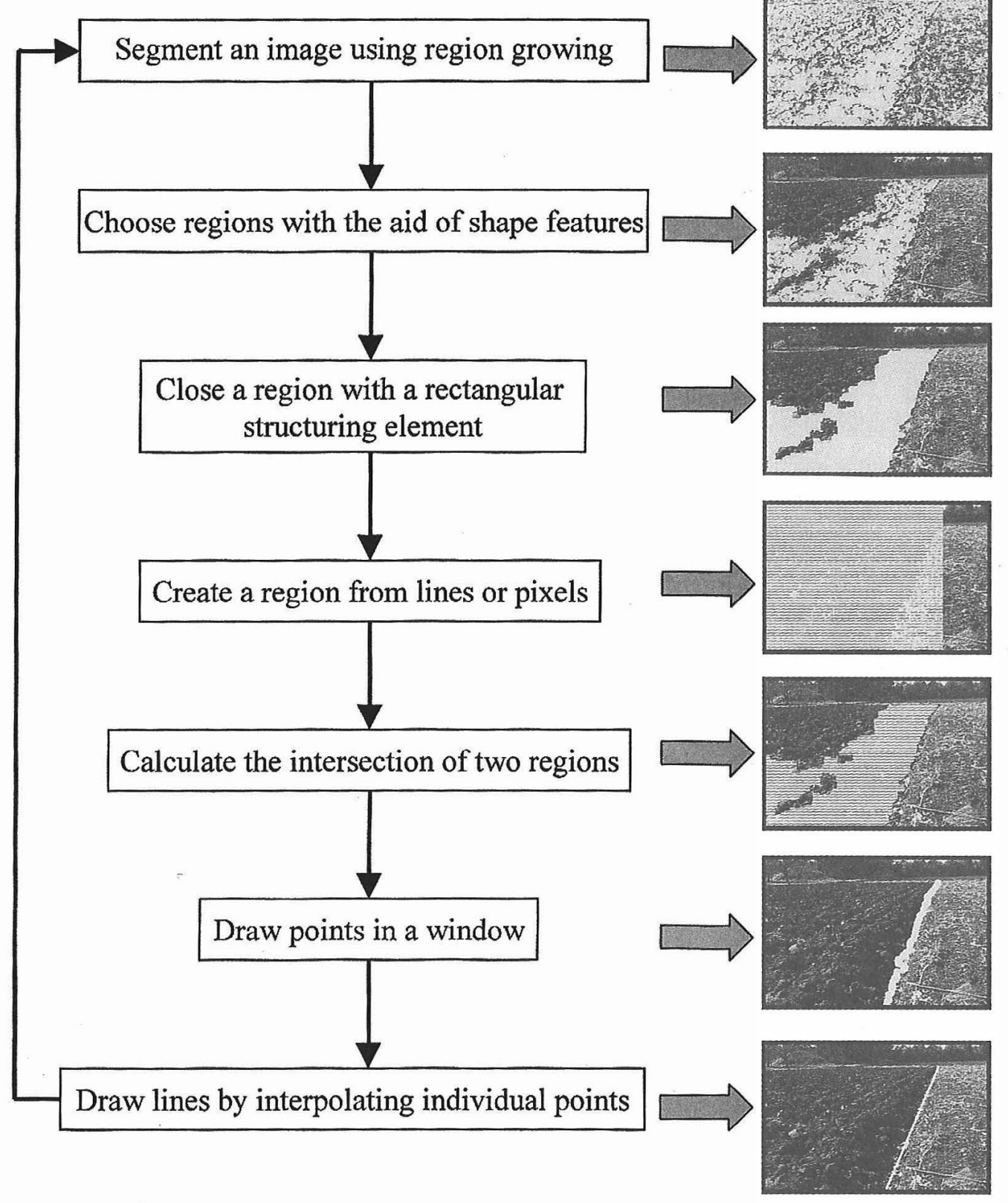

Fig. 2 Operational Procedures

(2). At this stage, we employed the width of a region as its shape-specific feature.

Following this, after calculating the minimum rectangular in parallel with the coordinate axes enclosing the entire image, the intersecting region obtained is to be represented in points. Finally, lines interpolating individual points are to be obtained and displayed in the image.

We extracted the boundary region following the abovedescribed procedure.

\section{Results of Analysis and Discussions}

1) Analysis using static images

In the areas related to our research, binary processing 
has been generally used to analyze test images. But in our project, this technique lacks versatility because applying it would require changing the threshold depending whether it is fine or cloudy. We therefore developed an image processing program capable of treating a 24-bit color image itself by using the algorithm shown in Figure 2. Figure 3 is a static image converted by this method from an animation image of the plowed test field taken when it was fine. From this test image, we gathered technical information used to animation image-based real-time recognition of the field state, which we will describe in the latter part of this section. The curvy shape in Figure 4 shows the boundary region

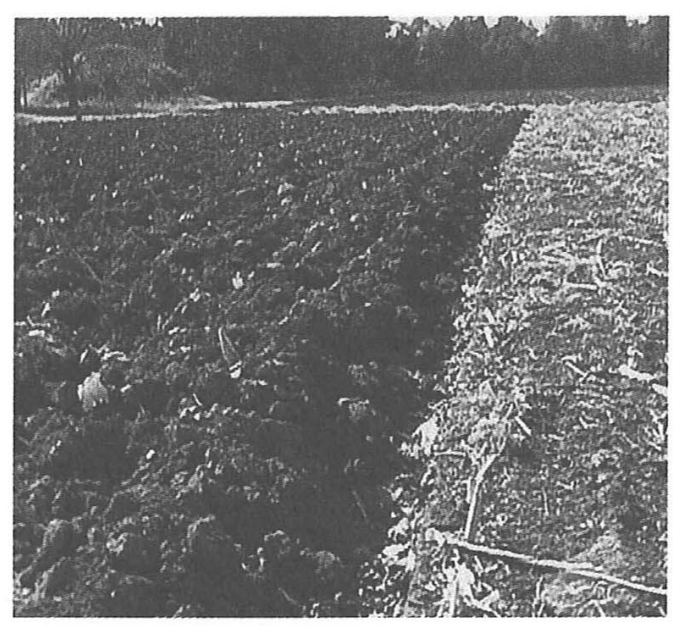

Fig. 3 Static image

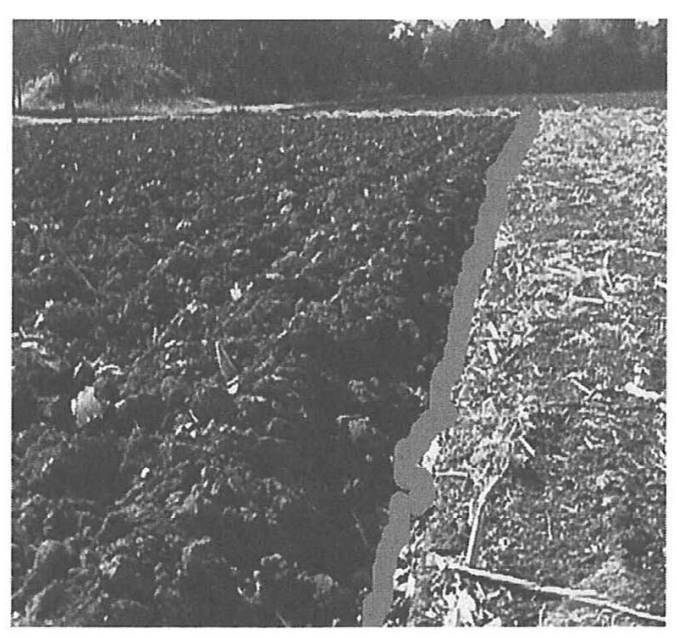

Fig. 4 Result of the analysis using static image (1) recognized. The curve actually comprises not a single line but a set of points arranged in sinuous form. For output visibility purposes, each point is displayed after being enlarged. Figure 5 shows the boundary region by using lines interpolating all points given in Figure 4. It is known from Figure 4 and Figure 5 that both tillage portion and the no-tillage portion are very clearly identified. Why lines are to be drawn is the need for feedback to the drive control of the autonomous tractor. We measured the run time of our image processing program after converting it into executable form with the above-explained method and found that it was capable of recognizing boundary regions at a speed of about 0.1 second per static image.

If an image processing program is applied to practical use, it seems inevitable that the background of the field as well as the tillage portion and the no-tillage portion will be included in the field of vision of the digital video camera mounted on the tractor. It is also expected that the accuracy of recognition will be affected by weather. We developed our image processing program for animation image-based field state recognition by taking these factors into consideration.

2) Analysis using animation images

In the initial stages of our work, we discerned boundary regions by using digitization, filtering and smoothing techniques by taking advantage of the fact that the clods to plow vary in brightness depending on the sunlight applied from the upper left direction in the test image.

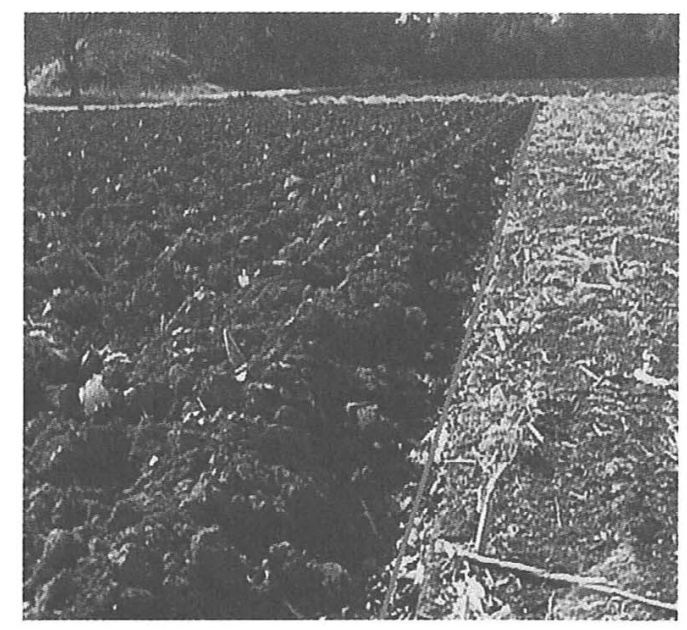

Fig. 5 Result of the analysis using static image (2) 
This made it easy to recognize the boundary between the tillage and no-tillage portions because the groove created between the two portions through plowing was shaded. That the clods of the tillage portion contained water and appeared dark brown also helped. When it was cloudy, however, the use of thresholds for digitization and parameter setting for filtering alone was found inadequate to clearly distinguish boundary regions because weak sunlight blurred the boundary.

We therefore analyzed animation images on the basis of the result of our static image-based analysis described

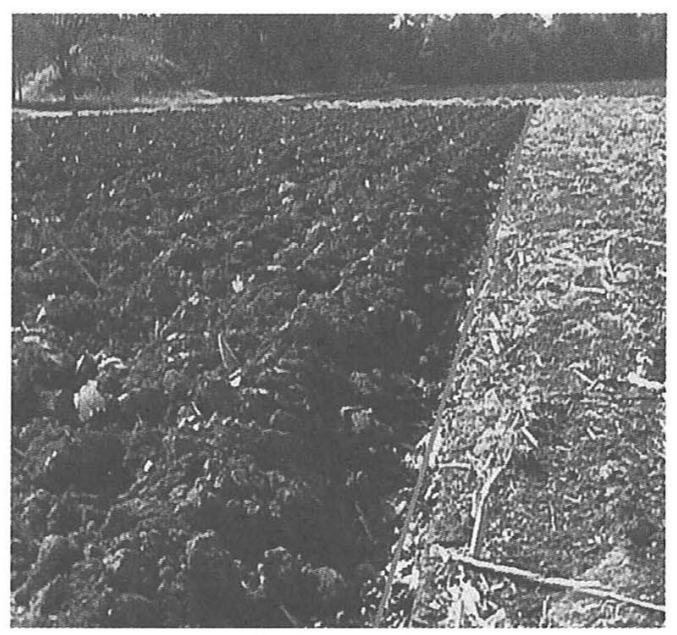

Fig. 6 Result of analysis by animation image (Weather: fine)

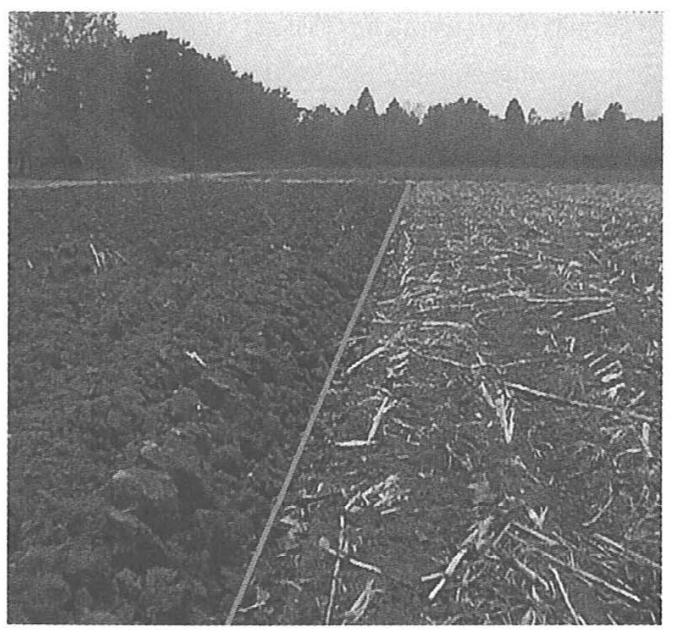

Fig. 7 Result of analysis by animation image (1) (Weather: cloudy) above. Figure 6 shows a 24-bit color animation image of the test field, taken one week after plowing, as it was processed by our image processing program. It can be known that animation image-based analysis delivered almost the same level of precision as that of static imagebased analysis (Figure 5) in discerning boundary regions. Figure 7 is an image taken under a cloudy sky from almost the same position as that of Figure 6 . Compared with Figure 6, it shows a line which was a maximum of about eight centimeters closer to the tillage portion in the bottom part of the image. At the end of plowing, almost the same result was obtained as in the case of fine weather. Also, as shown in Figure 8, a very similar result was obtained when images were taken from a position closer to the tillage and no-tillage portions under a cloudy sky. Given the fact that the width of the rear wheel tires of the tractor was 40 centimeters and that width of the groove created through plowing had the maximum width of about 40 centimeters, the results of recognition obtained through our work seem to be reasonable.

That it was possible to recognize the field status clearly even under a cloudy sky was attributable to the development of a new algorithm which does not depend on traditionally used binary processing, among others. Initially, we thought it necessary to eliminate the background elements contained in test images, such as trees and the sky, from them to identify the boundary

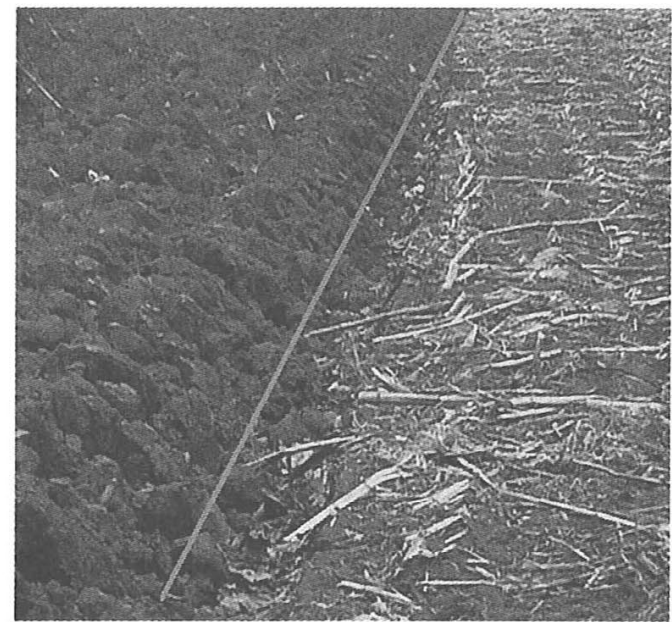

Fig. 8 Result of analysis by animation image (2) (Weather: cloudy) 
regions. Judging from our output results, however, such processing seems unnecessary. We measured the time required by our image processing program to handle about three minutes' length of animation image we used for our work and found that it took about 0.2 second to process one frame of the animation image. Such highspeed processing was realized thanks to the effective functioning of image division through region growing discussed when we explained the algorithm we employed.

If the autonomous tractor is to be put in practical operation, it would be necessary to take into consideration the time required to transmit to and process in the drive control unit in addition to the processing time required in the visual recognition unit. One method to reduce the processing time in the visual recognition unit is the increasing of the speed of the $\mathrm{CPU}$, because our program is designed to run on a versatile personal computer. Another method is the increasing of the number of image frames to be taken up per second and also the taking of animation images from the digital video camera in an asynchronous input mode. We will take up this approach in the future to keep in step with the operation control unit development group.

In the work reported in this paper, as part of our effort to develop a workstation for an autonomous bio-production robot, we intended to discern the tillage portion and the no-tillage portion of a test field by means of image processing technology. Our future challenges include the development of an image processing program applicable to diverse field conditions let alone plowing. We have set about developing a high-speed program capable of recognizing boundary regions independent of weather even when it is rainy. Another challenge is to incorporate the improved program into the autonomous tractor's operation control program, whose prototype is now in the process of making in our laboratory, to help realize the work of plowing utilizing image processing technology. We hope that in the next report we will be able to discuss our result of experiments with our speedier image processing program and its evaluation.

\section{Summary}

We developed an image processing program to discern the tillage portion and the no-tillage portion of a plowed field. The result of experiments with this program can be summarized as follows:

1) Analysis of static images resulted in relatively satisfactory recognition of the tillage portion and the no-tillage portion.

2) It took about 0.1 second to process one static image

3) Using animation images taken in fine weather, it was possible to discern the tillage portion and the no-tillage portion clearly.

4) Even with animation images taken under a cloudy sky, which have in the past been thought to be difficult to discern, it was possible to recognize boundary regions almost at the same level of accuracy as in the case of fine weather.

5) It took about 0.2 second to process one frame of animation image.

6) Incorporation of a region growing feature into our image processing algorithm helped to build a very high-speed image processing program.

\section{Acknowledgement}

This study was subsidized by basic scientific research (B) (Theme No. 09460113) sponsored by the Ministry of Education, Science, Sports, and Culture, Japan. The authors wish to express their thanks for this subsidy granted.

\section{Abstract}

As part of our research project on visual recognition of an autonomous agricultural tractor, we developed an image processing program that can detect on a real-time basis the movements of both tillage and no-tillage portions of an experimental field plowed by the tractor. Recognition is based on animation images taken by a video camera. Our analysis of static images, done for the purpose of verifying the reasonableness of parameters set to analyze animation images, allowed boundary regions to be recognized very clearly. The processing took about 0.1 second per static image. Analysis of animation images brought satisfactory field recognition results in both fine and cloudy conditions. Thanks to the use of algorithm incorporating the concept of region growing, our program was able to process animation images as fast as about 0.2 second per frame even for 
images taken in cloudy conditions, which have been difficult to recognize with traditional techniques.

\section{Key words}

Autonomous Travelling, Tractor, Image Processing, Detection of Field State

\section{Literature Cited}

BingQui Chen, Seisyu Tojo, Kengo Watanabe, Fusakazu Ai, B.K.Huang (1998): Studies on the Computer-eye of Rice Transplant Robot(Part3), Journal of Japanese Society of Agricultural Machinery, 60(5); 63-74.

BingQui Chen, Seisyu Tojo, Kengo Watanabe, Fusakazu Ai, B.K.Huang (1999): Studies on the Computer-eye of Rice Transplant Robot(Part4), Journal of Japanese Society of Agricultural Machinery, 61 (3); 57-64.

Hideo Hasegawa, Masayuki Koike, Tomohiro Takigawa (1998): Studies on workstation for autonomous bioproduction robot, Paper of No.57, Annual Meeting of the Japanese Society of Agricultural Machinery; 377378.

自律走行トラクタの視覚部に関する研究 一画像処理による围場状態の認識—

長谷川英夫* · 澈川具弘* - 小池正之* - 余田 章* . 坂井直樹 $* *$

\section{摘 要}

本報では, 自律走行トラクタの視覚部に関する研 究の一環として, プラウ耕を施用した供試围場をデ ジタルビデオカメラで撮影し，その24bitカラー動画 像から耕うん部と未耕うん部をリアルタイムに識別 する画像処理プログラムを開発した。まず，動画像 を用いた識別を行う前に，供試設定パラメータを検 証する目的で実施した静止画像による解析におい て，境界領域は極めて明確に識別することが可能と なり，開発したアルゴリズム及び設定パラメータの 有効性が明らかとなった。静止画像の処理時間を計 測したところ，画像 1 枚当たり約 0.1 秒で处理する ことができた。一方，動画像による解析では，これ
Hideo Hasegawa, Masayuki Koike, Tomohiro Takigawa (1999): Studies on workstation for autonomous bioproduction robot, Paper of No.58 annual Meeting of the Japanese Society of Agricultural Machinery; 371-372. Shiro Hirooka, Hideo Terao, Mamoru Kubota (1997): Vehicle Recognition Method by Image Processing with Intelligent System, Journal of Japanese Society of Agricultural Machinery, 59(5); 99-105.

Takahiro Kanuma, Tsuguo Okamoto, Toru Torii (1997): Image Analysis of Crop Row and Position Identification (Part1), Journal of Japanese Society of Agricultural Machinery, 59(2); 57-63.

Tomohiko Irimajiri, Mamoru Kubota, Hideo Terao (1995): Development of Fast Vehicle Recognition Algorithm in a Farming Environment, Journal of Japanese Society of Agricultural Machinery, 57 (3); 121-129.

Toru Torii, Tsuguo Okamoto, Akira Takamizawa, Takahiro Kanuma (1997): Image Analysis of Crop Row and Position Identification (Part2), Journal of Japanese Society of Agricultural Machinery, 59 (5); 37 -44 .

まで識別が困難であるとされてきた曼天時の画像に 対してもアルゴリズムに採用した領域成長を用いる ことにより，明確な識別が可能となった，晴天時及 び曼天時の識別結果を比較すると, 最大で約 $8 \mathrm{~cm}$ の 差異が生じた。しかし, 後車輪片側のタイヤ幅 $40 \mathrm{~cm}$ の供試トラクタが, プラウ耕によって生じた幅約 40 $\mathrm{cm}$ のれき溝に片輪を落として作業することを考慮す ると, 得られた識別結果は, 作業精度の観点からも 大きな支障はないと考えられたままた，動画像の処 理時間を計測したところ, 動画像 1 フレーム当たり 約 0.2 秒という高速な動画像処理プログラムを開発 することができた。さらに，開発した画像処理プロ グラムの識別精度をより一層向上する方策と処理時 間の短縮を図る方法について, 走行制御部との関連 において言及した。

$$
\text { キーワード }
$$

自律走行, トラク夕, 画像処理, 圃場認識

* 筑波大学農林工学系 ๆ 305-8572 茨城県つくば市天王台 1-1-1 ** 筑波大学農林学系 T 305-8572 茨城県つくば市天王台 1-1-1 